\title{
Possible decline in leatherback turtle Dermochelys coriacea nesting along the coast of Caribbean Central America
}

\author{
Sebastian Troëng, Didiher Chacón and Belinda Dick
}

\begin{abstract}
Leatherback turtle Dermochelys coriacea nesting has declined on Pacific beaches and as a result the species is considered Critically Endangered. Atlantic populations are, however, also important for the species' survival and therefore we undertook a study to quantify the size and nesting trend of the Caribbean Costa Rica and Panama leatherback turtle rookery. Tag returns show that post-nesting females from the rookery disperse throughout the Caribbean, Gulf of Mexico and North Atlantic. Aerial and track survey results were used to estimate 5,759-12,893 nests per year between San Juan river and Chiriquí beach, making this the fourth largest rookery worldwide. Monitoring results from three beaches (Tortuguero, Pacuare and Gandoca) were used to examine any temporal trend in nesting using nonparametric regression. Nesting appeared to decline slightly from 1995 to 2003 but the trend could be an artefact of interannual variation in nest numbers. Explanations for
\end{abstract}

the difference in nesting trends over the past 15 years for Pacific (rapid decline) and Caribbean (slight decline or stable) rookeries include: (1) hatching success on Caribbean beaches has been higher due to dispersed nesting, (2) fisheries bycatch has been greater in the Pacific, and (3) less overlap between fishing areas and leatherback turtle habitats in the Atlantic. Quantification of human-caused mortality of all life stages and knowledge of the marine habitats used by Atlantic leatherback turtles are required to facilitate the development and implementation of effective strategies to reduce threats and avoid a repeat of the decline that has occurred in the Pacific population.

Keywords Aerial survey, bycatch, Dermochelys coriacea, egg collection, leatherback turtle, nesting, tag returns, trend.

\section{Introduction}

Over the past 15 years there has been a decline in the nesting of leatherback turtles on beaches bordering the Pacific Ocean in Costa Rica, Malaysia and Mexico (Chan \& Liew, 1996; Eckert \& Sarti, 1997; Reina et al., 2002). The $>90 \%$ decline in leatherback turtle nesting has been attributed to egg collection and incidental capture in gillnet and longline fisheries (Chan \& Liew, 1996; Eckert \& Sarti, 1997; Spotila et al., 2000). As a result of the drastic decline in Pacific rookeries, the leatherback turtle is classified as Critically Endangered on the IUCN Red List (IUCN, 2003). However, there is controversy over the status of the species, with rookeries outside the Pacific basin reported to be stable or increasing (Hughes, 1996; Chevalier \& Girondot, 2000; Dutton et al., 2000).

\footnotetext{
Sebastian Troëng (Corresponding author) Caribbean Conservation Corporation, Apdo. Postal 246-2050, San Pedro, Costa Rica.

E-mail sebastian@cccturtle.org

Didiher Chacón Asociación ANAI, Apdo. 170-2070, Sabanilla, Montes de Oca, San José, Costa Rica.

Belinda Dick La Reserva Pacuare, Avenidas 10 y 12, Calle 21\#1065, San José, Costa Rica.
}

Received 27 August 2003. Revision requested 6 November 2003. Accepted 6 June 2004.
Threats to leatherback turtle survival persist in many locations. In the Atlantic Ocean killing of nesting females (Troëng, 2000; Troëng et al., 2002), illegal egg collection (Chacón, 1996; Troëng et al., 2002) and the effects of fisheries are causes for concern (Chevalier \& Girondot, 2000; NMFS-SEFSC, 2001). The extent of human induced mortality on nesting beaches varies between rookeries. Extensive migrations undertaken by leatherback turtles (Girondot \& Fretey, 1996; Hughes et al., 1998) mean that individuals from geographically separated rookeries may share feeding areas. Human activities that affect shared feeding grounds and cause mortality of juvenile and adult life stages of highly migratory and slowly maturing species can have widespread consequences (Tuck et al., 2003). The rapid nesting declines spanning broad sections of the Pacific suggests that individual rookery trends are not only local indicators but may indicate the trend for their ocean basin. If severe threats to survival affect distant rookeries analogously, trends in individual rookeries may have implications for the global survival of the leatherback turtle.

Along Caribbean Central America leatherback turtle nesting occurs predominantly from March to mid-July, although low-level nesting has been observed from January and as late as August (Chacón, 1999). Studies of the rookery began in the 1950s with descriptions of 


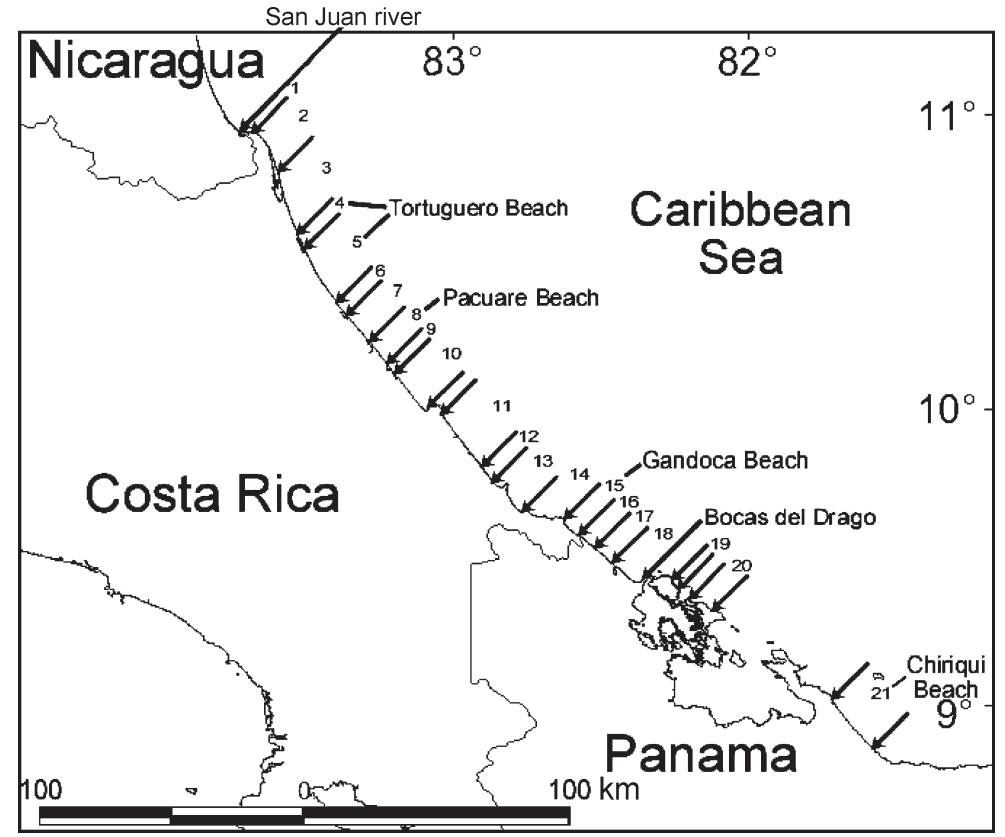

Fig. 1 The section of the Atlantic coast, from southern Nicaragua to northern Panama, surveyed from the air, with the location of all 21 surveyed beaches, including the three index beaches (see Table 1). nesting behaviour and biometric characteristics (Carr \& Ogren, 1959). More comprehensive studies to quantify nesting and tag females were initiated in the 1980s (Berry, 1987; Hirth \& Ogren, 1987). In 1990, regular surveys and tagging began on beaches from northern Costa Rica to northern Panama (Campbell et al., 1996; Chacón, 1999). In 2003 at least 11 projects monitored leatherback turtle nesting between the San Juan river and Chiriquí Beach (Fig. 1). Here, we present results from the three beaches (Tortuguero, Pacuare and Gandoca) with the most long-term monitoring records.

The leatherback turtle's Critically Endangered status is based predominantly on nesting declines recorded on Pacific beaches. But the sizes and trends of Atlantic leatherback turtle rookeries and threats to Atlantic populations are also important for the species' survival, and therefore our objectives were to determine the size and nesting trend for the leatherback turtle rookery of Caribbean Costa Rica and Panama, and to identify conservation and research priorities.

\section{Methods}

Monel \#49 tags (National Band \& Tag Co., Newport, USA) are attached to the rear flippers of nesting leatherback turtles. A total of 5,653 female leatherback turtles have been tagged from 1976 to 2003 on three 'index' beaches (Tortuguero $n=605$, Pacuare $n=2,297$, Gandoca $n=2,751)$. Each tag has a unique number and states that a reward is available (US \$5.00) for returning it to the University of Florida, USA. Only turtles stranded dead or observed in the ocean were included in this study. If the exact tag recapture location was not reported, we estimated a position based on the description of the recapture site. All tagging was conducted under research permits from the Ministry of Environment and Energy of Costa Rica.

In Tortuguero, Caribbean Conservation Corporation initiated track surveys in 1995. Approximately once per week a track surveyor records leatherback turtle tracks from the previous night. Nests and non-nesting emergences are recorded separately. The number of surveys varied (13-21, mean $18 \pm$ SD 2.5) per leatherback turtle nesting season for 1995-2003. A General Additive Model (GAM) with a robust quasi-likelihood error function, artificial end dates of 20 February and 10 July (9 July for leap years) weighted at 0.1 , was used to fit a curve to track survey results (weighted at 1.0) and produce nest estimates for each date (Bjorndal et al., 1999). The artificial end dates were given a lower weight in order to minimize their influence on annual nest number estimates. Negative estimates were trimmed from the beginning and end of each season. Annual nest numbers were estimated by integrating (interval 0.125) the GAM estimates using Berkeley Madonna software (Macey et al., 2000). Since 2000, surveys to estimate the proportion of illegally collected nests were conducted every 3 days between mid-March and the end of May/early June. Nests were considered illegally removed if there were ample footprints around the nest, evidence of digging and broken eggshells at the sand surface.

Since 1994 the Endangered Wildlife Trust has implemented daily nest counts from 7 March to July in Pacuare Nature Reserve. Since 2000 illegal egg collection in 
Pacuare has been evaluated using the same criteria as those employed at Tortuguero. Since 1991 Asociación ANAI has conducted daily nest counts on Gandoca beach from 1 February to July (Chacón, 1999). All tracks where a nest is believed to have been deposited are recorded. Notes are also kept on illegal egg collection.

To minimize the effect of nest variability only years with surveys on all three beaches were included in the trend analysis. A nonparametric regression model using BayesX with Markov field random smoothness priors and a Bayesian smoothing spline was employed to calculate trends with $95 \%$ credible intervals (Fahrmeir \& Lang, 2001; Balazs \& Chaloupka, 2004).

Aerial surveys (which included the three index beaches) from southern Nicaragua to northern Panama were conducted in a Cessna 185 flying at an altitude of $30-100 \mathrm{~m}$ at $185-225 \mathrm{~km} \mathrm{hr}^{-1}$. All surveys were conducted in the morning (8.00-10.35) in a north to south direction beginning at the San Juan river (Fig. 1). The pilot flew $10 \mathrm{~m}$ off the beach to allow the observers to see the entire coastline. All tracks where a turtle had made a body pit were counted as nests. Both fresh and old nests were counted. During these surveys two observers counted tracks. Overall observer variation averaged $1.6 \pm$ SD 2.5 nests per beach section. To ensure consistency, counts by the observer (ST) who participated in all surveys were used for analysis (Table 1). Beach width was classified as narrow (high tide mark at vegetation line), medium (high tide mark $0.5-10 \mathrm{~m}$ from vegetation line) or wide (high tide mark $\geq 10 \mathrm{~m}$ from vegetation line). All flights had approval from aviation authorities in Nicaragua, Costa Rica and Panama.

High tides and rough seas can erase leatherback turtle tracks and lead to underestimation of nesting, particularly on narrow beaches. To correct aerial survey results for variation in beach width, adjustment factors were calculated for Tortuguero (medium width), Pacuare (wide) and Gandoca (narrow) beaches (Equation 1.1).

$$
\begin{aligned}
& \text { Adjust }_{w}=A_{x} / \operatorname{Prop}_{x}\left(A_{\text {Tort }}+A_{\text {Pac }}+A_{\text {Gan }}\right) \\
& \text { Prop }_{\text {index beaches }}=\left(\left(B_{\text {Tort }} \times \text { Adjust }_{w}\right)+\left(B_{\text {Pac }} \times \text { Adjust }_{w}\right)+\right. \\
& \left.\left(B_{G a n} \times \text { Adjust }_{w}\right)\right) / \sum_{x=1}^{21}\left(B_{x} \times \text { Adjust }_{w}\right)
\end{aligned}
$$

1.2

$A_{\text {beach 1-21 }}=\left(A_{\text {Tort }}+A_{\text {Pac }}+A_{\text {Gan }}\right) /$ Prop $_{\text {index beaches }}$

Where Adjust $_{W}=$ adjustment factor for beaches with beach width $W, \mathrm{~A}_{\mathrm{x}}=$ annual nest number estimate for beach section $x$, Prop $_{x}=$ proportion of index beach nests deposited on beach section $x$ as recorded during aerial surveys, $B_{x}=$ number of nests on beach $x$ as recorded during aerial surveys, Tort $=$ Tortuguero, $P a c=$ Pacuare and $\mathrm{Gan}=$ Gandoca.
Corrected aerial survey results were used to calculate the proportion of nests laid on the three index beaches and to extrapolate annual nest number estimates for index beaches to the entire coast surveyed by air (Equations 1.2 and 1.3).

\section{Results}

Tags from 21 stranded or captured leatherback turtles were returned from USA $(\mathrm{n}=13)$, Cuba $(\mathrm{n}=3)$, Nicaragua $(\mathrm{n}=2)$, Canada $(\mathrm{n}=1)$, Spain $(\mathrm{n}=1)$ and Morocco $(n=1)$ (Fig. 2).

Annual leatherback turtle nesting varied, with 5741,623 nests $\mathrm{yr}^{-1}$ at Tortuguero, $490-1,286$ nests $\mathrm{yr}^{-1}$ at Pacuare, and 405-1,135 nests $\mathrm{yr}^{-1}$ at Gandoca (Fig. 3). All index beaches experienced a slight decline in nesting over the study period (Fig. 3). However, the $95 \%$ credible interval for the trend is wide (Fig. 3). Illegal egg collection declined continuously until 2002. In 2003 illegal egg collection increased on all index beaches (Fig. 3).

For years with aerial surveys, it is estimated that nests deposited on the three index beaches accounted for $45-50 \%$ of all nests observed between the San Juan river mouth and Bocas del Drago (Fig. 1). For 2002 and 2003, index beaches accounted for $27-32 \%$ of nests between the San Juan river and the end of Chiriquí beach (Table 1).

We estimate that 3,686-7,736 nests $\mathrm{yr}^{-1}$ are deposited between the San Juan river and Bocas del Drago and that 5,759-12,893 nests $\mathrm{yr}^{-1}$ are laid between the San Juan river and the end of Chiriquí beach (Table 1, Fig. 1). Clutch frequency for leatherback turtles can vary between rookeries and nesting seasons (Girondot \& Fretey, 1996; Reina et al., 2002) but the clutch frequency for the studied rookery is unknown. We applied the commonly used 5 nests per female (Spotila et al., 1996; Fretey \& Billes, 2000; Andrews \& Shanker, 2002) to estimate rookery size at 1,152-2,579 nesting females per year (Table 2).

\section{Discussion}

Tag returns from Tortuguero, Pacuare and Gandoca emphasize the wide distribution of habitats and migratory routes used by leatherback turtles in the Caribbean, Gulf of Mexico and North Atlantic, extending at least from $2^{\circ}$ to $50^{\circ} \mathrm{N}$ and $9^{\circ}$ to $97^{\circ} \mathrm{W}$ (Collard, 1990; Girondot \& Fretey, 1996; Eckert, 1998; Lagueux, 1998; NMFSSEFSC, 2001; Ferraroli et al., 2004; Hays et al., 2004). This broad distribution, including marine areas under the national jurisdiction of several countries and the high seas, stresses the challenge of developing adequate leatherback turtle conservation policies. Although 20 of 21 tag returns were from stranded or floating carcasses, 


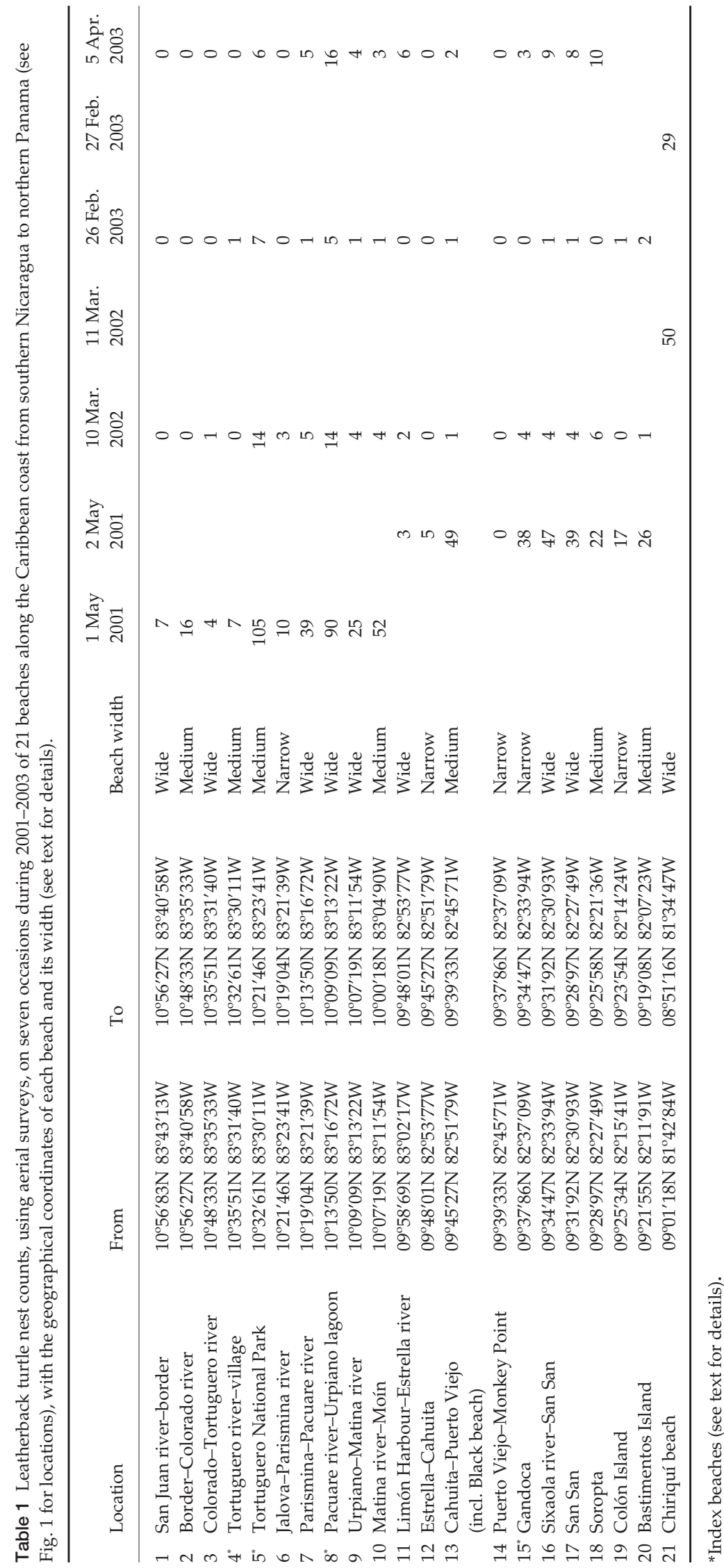




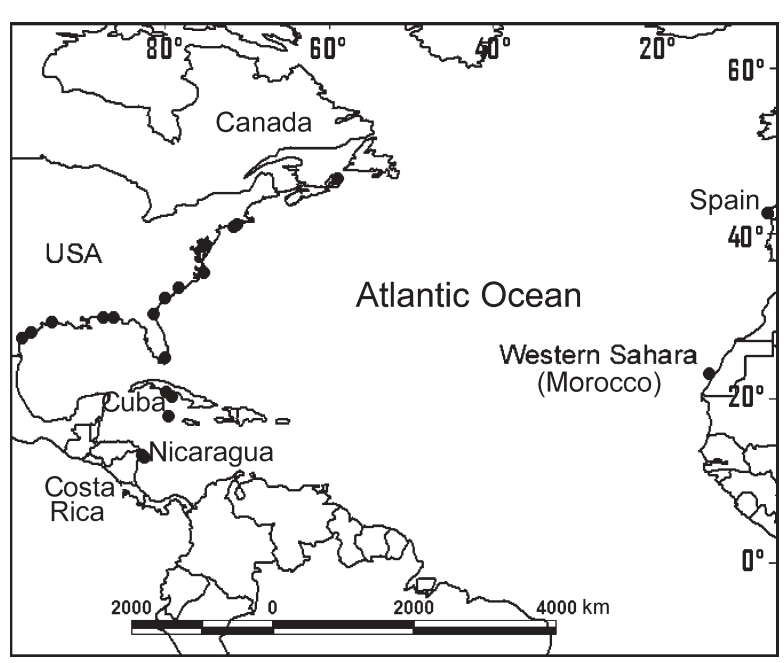

Fig. 2 Tag return locations (filled circles) for leatherback turtles tagged on the three index beaches of Tortuguero, Pacuare and Gandoca beaches, Costa Rica.

interaction with fisheries and boat collisions could not be ruled out in any of the cases (the exception being a report of a live turtle in Canada). An international effort is needed to limit incidental leatherback turtle capture in fisheries in areas where these activities overlap with turtle habitat and migratory routes (Ferroli et al., 2004; Hays et al., 2004). The Inter-American Convention for Sea Turtle Protection and Conservation, the Convention on Migratory Species and regional fisheries organizations should be explored as international mechanisms to strengthen leatherback turtle conservation efforts. Development and implementation of fishing gear to reduce leatherback turtle bycatch, such as turtle excluder devices with larger openings and circle hooks, can only be considered the first steps in such a process (Watson et al., 2003). Failure to take action in areas where fisheries and leatherback turtles interact in the Atlantic may result in a repetition of the decline observed in Pacific leatherback turtle rookeries.

Observation of tagged individuals shows that at least some leatherback turtles exhibit limited nest site fidelity. Individual leatherback turtles have been recorded to move between beaches within and between nesting seasons. For example, individuals tagged on beaches in Colombia and Honduras have been observed on Costa Rican nesting beaches. One leatherback turtle tagged in Pacuare dug an egg chamber on Jensen Beach $\left(27^{\circ} 15^{\prime} \mathrm{N}\right.$, $80^{\circ} 13^{\prime} \mathrm{W}$ ) in Florida, USA (D. Bagley, pers. comm.).

We analysed 9 years (1995-2003) of leatherback turtle nesting data from three index nesting beaches. Variability in nesting between years means that continued monitoring is needed to discern long-term population trends. Although sea turtle nest numbers vary and are thought to be influenced by environmental variables, variation is normally less for leatherback than for green turtles (Broderick et al., 2001).

Illegal collection of leatherback turtle nests in Costa Rica declined from $78 \%$ in 1987 (Berry, 1987) to $11.5 \%$ on the relatively well protected index beaches in 2003. For slow growing and late maturing species, even low levels of increased egg mortality on nesting beaches coupled with mortality of adults and juveniles in fisheries bycatch can result in population decline (Musick, 1999). Leatherback turtle egg collection has been prohibited in Costa Rica since 1948 (Legislative Assembly, 1948), leatherback turtle hunting has been banned since 1984 (Government of Costa Rica, 1984) and a law that established prison sentences for egg collection entered into force in 2002 (Legislative Assembly, 2002). It appears the new law has not functioned as a deterrent in the short-term, as illegal egg collection increased in 2003. This can be explained by the delay of 1 or more years between arrests and cases going to trial. The new law was applied in at least two court cases in late 2003 and both resulted in prison sentences for illegal egg collection (E. Chamorro, pers. comm.). These and future sentences may deter illegal egg collection in the long-term. The new law can only be applied if illegal egg collectors are arrested. Therefore, increased enforcement on nesting beaches is urgently needed.

The declining nesting trend may be an artefact of interannual nesting variation during the relatively short time period for which nesting data are available. However, experience from Pacific beaches show that leatherback turtle declines can be rapid (Spotila et al., 2000). This is particularly true if threats to leatherback turtle survival, such as illegal egg collection and incidental capture in fisheries, occur simultaneously. Quantifying human induced mortality of leatherback turtles at all life stages is a priority.

The aerial surveys indicated variability in the proportion of nests laid on the index beaches. However, the mean annual proportion of nests laid on these beaches remained at $45-50 \%$ of nests between the San Juan river and Bocas del Drago, and $27-32 \%$ of nests between the San Juan river and the end of Chiriquí beach. The three index beaches are well separated geographically, reducing the likelihood that nests laid by female turtles switching between Gandoca in the south and Tortuguero and Pacuare in the north were not recorded. Therefore, the slight decline in nesting is not likely to be the result of female leatherback turtles changing nesting beaches.

Our estimate of 3,686-7,736 nests per year between the San Juan river and Bocas del Drago is similar to the 1987 estimate of 4,987 leatherback turtle nests for the entire coast of Caribbean Costa Rica (Berry, 1987). It appears leatherback turtle nesting in Caribbean Costa Rica has remained stable or experienced a slight decline over the 


\section{A. Tortuguero}
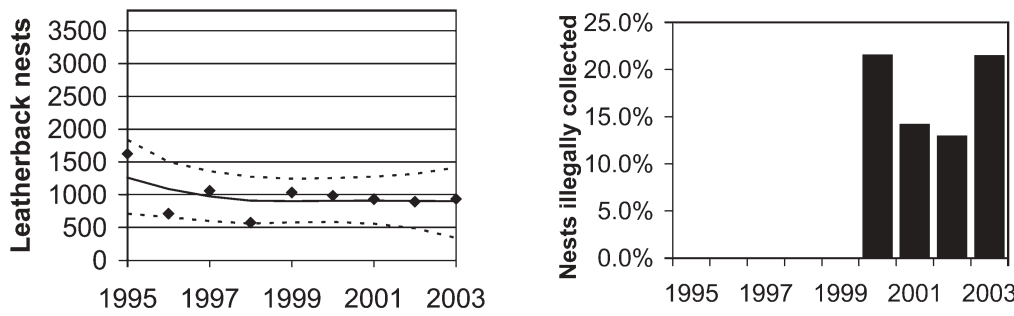

B. Pacuare
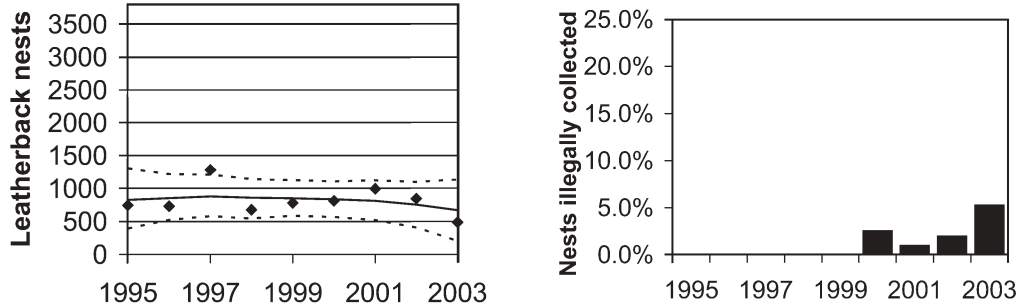

C. Gandoca
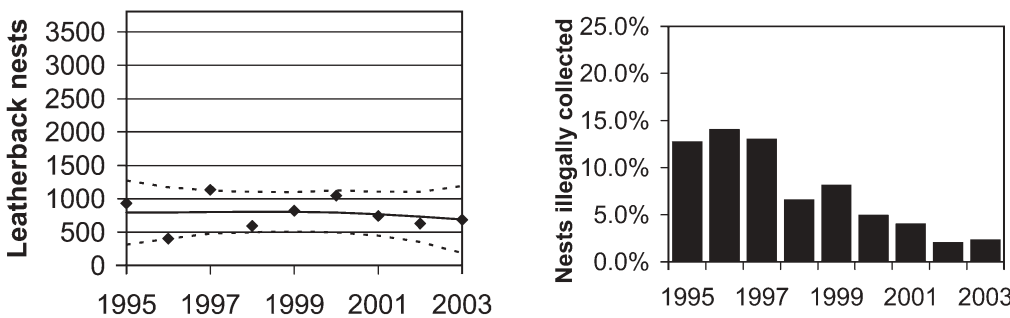

\section{All three index beaches}
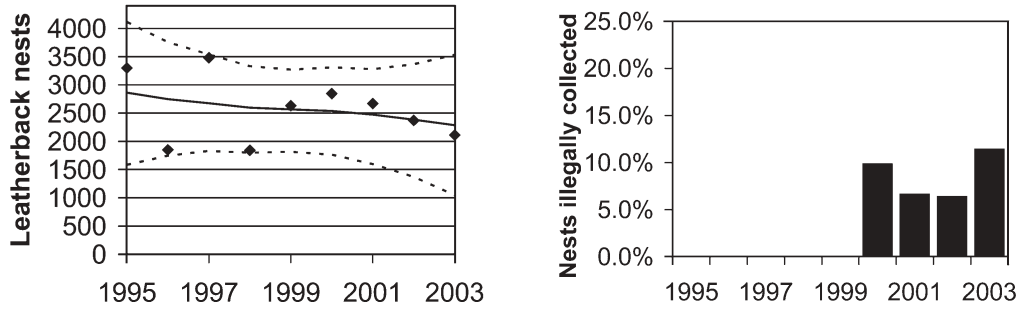

Fig. 3 Number of leatherback turtles nesting and illegal egg collection at the three index beaches (see Fig. 1 for locations) and overall from 1995 to 2003. Solid line trend curves are derived with a Bayesian nonparametric regression model; $95 \%$ credible intervals indicated with dashed lines (see text for details). past 15 years, a markedly different trend from the rapid nesting decline recorded on Pacific beaches of Costa Rica (Spotila et al., 2000).

We propose three possible explanations for the difference in the trend of leatherback turtle nesting in Caribbean (slight decline or stable) and Pacific Central America (rapid decline). Firstly, hatching success might have been higher on Caribbean beaches as nesting is more dispersed (Tucker, 1990). Nesting on the Pacific coast is restricted mainly to Playa Grande and nearby beaches in Costa Rica (Reina et al., 2002) and egg collection might have been close to $100 \%$ before protection measures were implemented. On the other hand, leatherback turtle egg collection is virtually non-existent on Chiriquí beach (C. Ordoñez, pers. comm.). Dispersed nesting ensures that at least some nests are laid on beaches where illegal egg collection is less prevalent.

Secondly, incidental capture of leatherback turtles in the Pacific might have become a problem before Atlantic leatherback turtle populations were seriously affected by fisheries. In the 1990s the number of hooks set in longline fisheries increased both in the north and the tropical Atlantic Ocean (NMFS-SEFSC, 2001) and it is possible that juvenile and adult leatherback turtle mortality has increased as a result. Delayed maturity in leatherback turtles means that the slight decline in nesting observed 
Table 2 Major leatherback turtle rookeries worldwide, with number of nests per year, clutch frequency and number of females per year.

\begin{tabular}{|c|c|c|c|c|}
\hline Location & Nests per year & Clutch frequency* & Females per year & References \\
\hline French Guiana \& Suriname & $18,481-55,654$ & 7.5 & $2,464-7,421$ & $\begin{array}{l}\text { Girondot \& Fretey (1996), } \\
\text { Girondot et al. (2002), } \\
\text { M. Girondot (pers. comm.) }\end{array}$ \\
\hline Southern coast, Gabon & 29,000 & 5 & 5,800 & Fretey \& Billes (2000) \\
\hline North Trinidad, Trinidad \& Tobago & $9,000-10,000$ & & $1,800-2,000$ & Eckert (2001) \\
\hline Caribbean Costa Rica \& Panama & $5,759-12,893$ & & $1,152-2,579$ & This study \\
\hline Papua, Indonesia & $3,000+$ & & $600+$ & Putrawidjaja (2000) \\
\hline Great Nicobar island, India & 1,690 & 5 & 338 & Andrews \& Shanker (2002) \\
\hline Pacific coast, Mexico & $<1,250$ & & $<250$ & Eckert \& Sarti (1997) \\
\hline Playa Grande, Costa Rica & 1,220 & $4.3-7.0$ & 231 & Reina et al. (2002) \\
\hline St Croix, US Virgin Islands & 95-289 & 5.26 & $18-55$ & Boulon et al. (1996) \\
\hline
\end{tabular}

*Clutch frequency used to convert nests to females; for rookeries without clutch frequency estimates, 5 nests per female was used (Spotila et al., 1996).

in this study could be the beginning of a trend similar to that of Pacific rookeries.

Thirdly, in the Atlantic there may be less overlap between fishing areas and leatherback turtle habitats than in the Pacific. This would mean less incidental catch and higher survival rates for Atlantic leatherback turtles. Analysis of fisheries observer data and satellite telemetry studies aimed at quantifying the overlap between leatherback turtle habitats and fishing areas are urgently needed. Fisheries regulation and enforcement may also be necessary to reduce incidental mortality.

Meylan et al. (1985) reported leatherback turtle nesting on beaches located to the east of the coastal section covered by aerial surveys in this study, and Dutton et al. (1999) concluded there was no significant difference in mtDNA haplotype frequencies for leatherback turtles nesting in French Guiana/Suriname, Caribbean Costa Rica and Florida, USA. Hence, it appears that leatherback turtles nesting in Caribbean Costa Rica and Panama belong to a population whose nesting range extends along the entire Caribbean coast of Central America and possibly to South America. As we only surveyed a part of the population's nesting range, our estimate of rookery size must therefore be considered conservative.

We recommend continued aerial surveys to track any changes in the spatial distribution of nesting. Extending surveys to include beaches in eastern Panama would be desirable, and the organizations Caribbean Conservation Corporation and Lighthawk are intending to carry out such surveys in the near future.

We conclude that the leatherback turtle rookery of Caribbean Central America represents one of the four largest remaining rookeries worldwide, together with French Guiana/Suriname, Gabon and Trinidad (Table 2). For the rookery to remain globally significant it is crucial that illegal egg collection in Costa Rica and Panama is reduced and that incidental capture in fisheries throughout the Atlantic basin is kept to a minimum. To address anthropogenic threats we need to increase our knowledge of the location and extent of marine habitats used by leatherback turtles. Satellite telemetry to document the movements of post-nesting leatherback turtle females has been initiated at Tortuguero $(n=2$ in 2003, $\mathrm{n}=2$ in 2004) and in Gandoca ( $\mathrm{n}=1$ in 2004) but increased sample sizes are needed to identify critical areas used by leatherback turtles from the studied population.

\section{Acknowledgements}

We thank all researchers and volunteers in Gandoca, Pacuare and Tortuguero. We especially thank $\mathrm{H}$. Alguera, A. Barragán, C. Campbell, L. Corea, R. Corea, J. Denham, C. Fernández, E. Harrison, C. Lagueux, P. Lahanas, L. Matute, A. Rankin, E. Rankin, C. Reyes, S. Rodriguez, E. Vargas and E. Vélez. David Smith, piloted the aerial surveys. T. Amos, L. Belskis, A. Bruguera, T. Davis, K. Durham, P. Eliazar, J. Gourdani, D. Gunter, C. Hope, M. James, C. Lagueux, W. Muller, N. Norman, P. Norman, A. Piñero, E. Ogley, C. Reid, W.G. Rivers, J. Simmons, A. Smith, L. Spence, A. Tang and W. Teas reported tag recoveries. The National Environmental Authority of Panama, Costa Rica's Ministry of Environment and Energy and National Coast Guard Service are thanked for protecting leatherback turtles and their nests. Two anonymous reviewers provided comments that considerably strengthened the paper.

\section{References}

Andrews, H. \& Shanker, K. (2002) A significant population of leatherback turtles in the Indian Ocean. Kachhapa, 6, 19.

Balazs, G. \& Chaloupka, M. (2004) Thirty-year recovery trend in the once depleted Hawaiian green sea turtle stock. Biological Conservation, 117, 491-498.

Berry, F. (1987) Aerial and ground surveys of Dermochelys coriacea nesting in Caribbean Costa Rica, 1987. In Proceedings of the Second Western Atlantic Turtle Symposium. NOAA Technical Memorandum, NMFS-SEFC-226, 305-310. 
Bjorndal. K.A., Wetherall, J.A., Bolten, A.B. \& Mortimer, J.A. (1999) Twenty-six years of green turtle nesting at Tortuguero, Costa Rica: An encouraging trend. Conservation Biology, 13, 126-134.

Boulon, R., Dutton, P. \& McDonald, D. (1996) Leatherback turtles (Dermochelys coriacea) on St. Croix, U.S. Virgin Island: fifteen years of conservation. Chelonian Conservation and Biology, 2, 141-147.

Broderick, A.C., Godley, B.J. \& Hays, G.C. (2001) Trophic status drives interannual variability in nesting numbers of marine turtles. Proceedings of the Royal Society of London B, 268, 1481-1487.

Campbell, C.L., Lagueux, C.J. \& Mortimer, J.A. (1996) Leatherback turtle, Dermochelys coriacea, nesting at Tortuguero, Costa Rica, in 1995. Chelonian Conservation Biology, 2, 169-172.

Carr, A. \& Ogren, L. (1959) The ecology and migrations of sea turtles, 3, Dermochelys in Costa Rica. American Museum Novitates, 1958, 1-29.

Chacón, D. (1999) Anidación de la tortuga Dermochelys coriacea (Testudines: Dermochelyidae) en playa Gandoca, Costa Rica (1990 a 1997). Revista de Biología Tropical, 47, 225-236.

Chacón, D., McLarney, W., Ampie, C. \& Venegas, B. (1996) Reproduction and conservation of the leatherback sea turtle Dermochelys coriacea (Testudines: Dermochelyidae) on Gandoca Beach. Costa Rica. Revista de Biología Tropical, 44, 853-860.

Chan, E. \& Liew, H. (1996) Decline of the leatherback population in Terengganu, Malaysia, 1956-1995. Chelonian Conservation Biology, 2, 196-203.

Chevalier, J. \& Girondot, M. (2000) Recent population trend for Dermochelys coriacea in French Guiana. In Proceedings of the $18^{\text {th }}$ Annual Symposium on Sea Turtle Biology and Conservation (compilers F.A. Abreu, R. Briseño, R. Márquez \& L. Sarti), pp. 56-57. NOAA Technical Memorandum, NMFS-SEFSC436.

Collard, S.B. (1990) Leatherback turtles feeding near a watermass boundary in the eastern Gulf of Mexico. Marine Turtle Newsletter, 50, 12-14.

Dutton, D.L, Dutton, P.H. \& Boulon, R. (2000) Recruitment and mortality estimates for female leatherbacks nesting in $\mathrm{St}$ Croix, U.S. Virgin Islands. In Proceedings of the $19^{\text {th }}$ Annual Symposium on Sea Turtle Biology and Conservation (compilers H. Kalb \& T. Wibbels), pp. 268-269. NOAA Technical Memorandum, NMFS-SEFSC-443.

Dutton, P.H., Bowen, B.W., Owens, D.W., Barragán, A. \& Davis, S.K. (1999) Global phylogeography of the leatherback turtle (Dermochelys coriacea). Journal of Zoology, 248, 397-409.

Eckert, K.L. (2001) Estado de conservación y distribución de Dermochelys coriacea. In Conservación de Tortugas Marinas en la Región del Gran Caribe - Un Diálogo para el Manejo Regional Efectivo (eds K.L. Eckert \& F.A. Abreu Grobois), pp. 25-33. WIDECAST, IUCN/Species Survival Commission Marine Turtle Specialist Group, WWF and UNEP-Caribbean Environment Programme.

Eckert, S. (1998) Perspectives on the use of satellite telemetry and other electronic technologies for the study of marine turtles, with references to the first year long tracking of leatherback sea turtles. NOAA Technical Memorandum, NMFS-SEFSC-415, 44-46.

Eckert, S.A. \& Sarti M., L. (1997) Distant fisheries implicated in the loss of the World's largest leatherback nesting population. Marine Turtle Newsletter, 78, 2-7.
Fahrmeir, L. \& Lang, S. (2001) Bayesian inference for generalised additive mixed models based on Markov random field priors. Applied Statistics, 50, 201-220.

Ferraroli, S., Georges, J.-Y., Gaspar, P. \& Le Maho, Y. (2004)

Where leatherback turtles meet fisheries. Nature, 429 , 521-522.

Fretey, J. \& Billes, A. (2000) Les plages du sud Gabon: dernière grande zone de reproduction de la planète pour la tortue-luth? Canopée, 17, I-IV.

Girondot, M. \& Fretey, J. (1996) Leatherback turtles, Dermochelys coriacea, nesting in French Guiana, 1978-1995. Chelonian Conservation and Biology, 2, 204-208.

Government of Costa Rica (1984) Hunting ban on threatened species of wild fauna and flora. La Gaceta, 67, 4 April 1984. [in Spanish]

Hays, G.C., Houghton, J.D.R. \& Myers A. (2004) Pan-Atlantic leatherback turtle movements. Nature, 429, 522.

Hirth, H. \& Ogren, L. (1987) Some aspects of the ecology of the leatherback turtle Dermochelys coriacea at Laguna Jalova, Costa Rica. NOAA Technical Report, NMFS 56, 1-14.

Hughes, G. (1996) Nesting of the leatherback turtle (Dermochelys coriacea) in Tongaland, Kwazulu-Natal, South Africa 1963-1995. Chelonian Conservation Biology, 2, 153-158.

Hughes, G.R., Luschi, P., Mencacci, R. \& Papi, F. (1998) The 7000-km oceanic journey of a leatherback turtle tracked by satellite. Journal of Experimental Marine Biology and Ecology, 229, 209-217.

IUCN (2003) 2003 IUCN Red List of Threatened Species. IUCN, Gland, Switzerland [http:/ / www.redlist.org, accessed 15 July 2004].

Lagueux, C.J. (1998) Marine turtle fishery of Caribbean Nicaragua: human use patterns and harvest trends. PhD thesis, University of Florida, Gainesville, USA.

Legislative Assembly (1948) Fisheries and marine hunting law, Law N ${ }^{\circ} 190$. Collection of Laws and Decrees, 1948 (2:2), 212-218.

Legislative Assembly (2002) Law for protection, conservation and recuperation of sea turtle populations, Law $\mathrm{N}^{\circ} 8325$. $\mathrm{La}$ Gaceta, 230, 28 November 2002. [in Spanish]

Macey, R., Oster, G., \& Zahnley, T. (2000) Berkeley Madonna User's Guide. Version 8.0. University of California, Berkeley, USA.

Meylan, A., Meylan, P. \& Ruiz, A. (1985) Nesting of Dermochelys coriacea in Caribbean Panama. Journal of Herpetology, 19, 293-297.

Musick, J.A. (1999) Ecology and conservation of long-lived marine animals. In Life in the Slow Lane: Ecology and Conservation of Long-Lived Marine Animals (ed. J.A. Musick), pp. 1-10. American Fisheries Society Symposium 23, Bethesda, USA

NMFS-SEFSC (2001) Stock Assessments of Loggerhead and Leatherback Sea Turtles and An Assessment of the Impact of the Pelagic Longline Fishery on the Loggerhead and Leatherback Sea Turtles of the Western North Atlantic. NOAA Technical Memorandum, NMFS-SEFSC-455. 226 pp.

Putrawidjaja, M. (2000) Marine turtles in Irian Jaya, Indonesia. Marine Turtle Newsletter, 90, 8-10.

Reina, R.D., Mayor, P.A., Spotila, J.R., Piedra, R. \& Paladino, F.V. (2002) Nesting ecology of the leatherback turtle, Dermochelys coriacea, at Parque Nacional Marino Las Baulas, Costa Rica: 1988-1989 to 1999-2000. Copeia, 2002, 653-664.

Spotila, J.R., Dunham, A.E., Leslie, A.J., Steyermark, A.C., Plotkin, P.T. \& Paladino, F.V. (1996) Worldwide population decline of Dermochelys coriacea: are leatherback turtles going extinct? Chelonian Conservation Biology, 2, 209-222. 
Spotila, J.R., Reina, R.D., Steyermark, A.C., Plotkin, P.T. \& Paladino, F.V. (2000) Pacific leatherback turtles face extinction. Nature, 405, 529-530.

Troëng, S. (2000) Predation of green (Chelonia mydas) and leatherback (Dermochelys coriacea) turtles by jaguars (Panthera onca) at Tortuguero National Park, Costa Rica. Chelonian Conservation Biology, 3, 751-753.

Troëng, S., Chacón, D. \& Dick, B. (2002) The Leatherback Turtle Dermochelys coriacea Nesting Population of Caribbean Central America, with An Emphasis on Costa Rica. Unpublished Report. Caribbean Conservation Corporation, Asociación ANAI and Endangered Wildlife Trust to the IUCN Leatherback Taskforce, San José, Costa Rica.

Tuck, G.N., Polacheck, T. \& Bulman, C.M. (2003) Spatio-temporal trends of longline fishing effort in the Southern Ocean and implications for seabird bycatch. Biological Conservation, 114, 1-27.

Tucker, A.D. (1990) A test of the scatter-nesting hypothesis at a seasonally stable leatherback rookery. In Proceedings of the Tenth Annual Workshop on Sea Turtle Biology and Conservation (compilers T.H. Richardson, J.I. Richardson \& M. Donnelly), pp. 11-14. NOAA Technical Memorandum, NMFS-SEFC278

Watson, J.W., Foster, D.G., Epperly, S. \& Shah, A. (2003)

Experiments in the Western Atlantic Northeast Distant Waters to Evaluate Sea Turtle Mitigation Measures in the Pelagic Longline Fisheries. NOAA, US Department of Commerce.

\section{Biographical sketches}

Sebastian Troëng conducts research and conservation in Costa Rica and Panama, and is interested in quantifying biological and economic consequences of conservation efforts.

Didiher Chacón is developing a sea turtle recovery plan with an ecosystem focus for Caribbean Costa Rica.

Belinda Dick's research focuses on the socioeconomic, biological, legal and political aspects of marine resource conservation 